\title{
Performance of Chickpea under Raised Bed Planting in Vertisols in Central India
}

\author{
Prashant Shrivastava $^{1}$, Yati Raj Khare ${ }^{1 *}$ and D.K. Pahalwan ${ }^{2}$ \\ ${ }^{1}$ Krishi Vigyan Kendra, Narsinghpur (M.P.), India \\ ${ }^{2}$ College of Agriculture, Hoshangabad (M.P.), India \\ *Corresponding author
}

\section{A B S T R A C T}

\section{Keywords \\ Chickpea, Vertisol, Raised bed, Bed planter}

\section{Article Info}

\section{Accepted:}

07 February 2018

Available Online:

10 March 2018
An assessment of raised bed sowing of chickpea was done during rabi season in the vertisols of Narsinghpur district of Madhya Pradesh in Central India. The study was conducted for two consecutive years viz. 2014-15 and 2015-16. Chickpea variety JG-63 was considered for the study. Average crop yield under the flat bed planting was observed to be $11.95 \mathrm{q} /$ ha whereas the same under the raised bed planting was $15.15 \mathrm{q} / \mathrm{ha}$. Thus an increase of nearly 28 percent was obtained in crop yield when planted on raised beds. The average net return in the case of raised bed planting was Rs. 29010/- per ha whereas that under raised bed planting was observed to be Rs. 42248/- per ha. Thus an increase of Rs. 13238/- per ha was observed under the raised bed planting. With regard to B: C ratio the one under raised bed planting (2.67) was found to be higher than that under the flat bed planting (2.205). Overall the raised bed planting performed better than the flat bed planting in the case of chickpea in vertisol region of central India.

\section{Introduction}

Protein malnutrition is a major problem in India. Enhancing the productivity of pulse crops has therefore become a major concern. Chickpea (Cicer arietenum) is one of the potential pulse crops in the country. It is grown in 8.3 million ha area with an annual production of 7.7 million tonnes and an average productivity of $928 \mathrm{~kg} / \mathrm{ha}$ (MOA 2013). Major area of chickpea is found in Madhya Pradesh, Rajasthan, Maharashtra, Karnataka, Andhra Pradesh and Uttar Pradesh. In most of the states the crop productivity is low as the traditional practices of cultivation are followed. Narsinghpur is a major pulse growing district in Madhya Pradesh. On an average about 89000 ha area is covered under chickpea in Narsingpur during rabi season. There is immense scope in the district for increasing the productivity of chickpea. Present investigation was undertaken for observing the role of planting method on chickpea in vertisols. Raised bed system of planting was compared with the flat bed method of planting prevalent in the district.

\section{Materials and Methods}

The trial was conducted in rabi season during the year 2014-15 and 2015-16 in farmers fields in vertisol in Narsinghpur district of 
Madhya Pradesh. Each year different fields were taken for the study. Each year the raised bed planting was done at five fields of size one acre each. A tractor drawn bed planter was utilized for raised bed planting of chickpea. Chickpea variety JG-63 was considered for the study. Ordinary seed cum fertilizer drill was utilized for the flat bed planting of chickpea. The seed rate under the raised bed planting was $50 \mathrm{~kg} /$ hectare.

Under the raised bed method sowing was done in two rows spaced at nine inch on each bed of fourteen inch width. Each bed was separated by a furrow. Under the flat bed planting the farmers stuck to their usual seed rate of 75 $\mathrm{kg} / \mathrm{ha}$. Irrigation was given through sprinklers at flowering and at pod formation stage. Data on crop yield was taken on actual yield per acre basis. Cost of cultivation and gross return were computed on prevalent market rates basis.

\section{Results and Discussion}

During the year 2014-15 the crop yield under raised bed planting was $12.8 \mathrm{q} / \mathrm{ha}$. This was higher by $2.5 \mathrm{q}$ over the flat bed planting. Thus the crop yield under the flat bed planting was obtained as $10.3 \mathrm{q} / \mathrm{ha}$. The average cost of cultivation was computed on the basis of prevalent market rates. It was observed that the cost of cultivation under the raised bed planting was computed to be Rs. Rs. 24700/per ha which was slightly higher than that computed under the flat bed planting. The gross return under the flat bed planting was computed to be Rs. 37970/- per ha which increased to Rs. 47195/- per ha under the raised bed planting. The net return was higher in case of raised bed planting. The average net return under raised bed planting was found to be Rs. 22495/- per ha. An additional amount of Rs. 8475/- per ha was fetched as net return under the raised bed planting against the flat bed planting.. The B: $\mathrm{C}$ ratio in case of raised bed planting was 1.91 as compared to 1.58 computed under the flat bed planting. Thus the results of raised bed planting were encouraging.

The same trial was conducted again during the year 2015-16 at different fields. Here again, the results supported the raised bed planting of chickpea. A crop yield of $17.5 \mathrm{q} / \mathrm{ha}$ was obtained in the raised bed planting. This was higher by $3.9 \mathrm{q} / \mathrm{ha}$ over the flat bed planting. The prevalent market rate of chickpea was Rs. 5050/- per q. The same was utilised for computing the gross returns. A gross return of Rs. 87500/- per q. was obtained under the raised bed planting. This was higher by Rs. 19500/- than that obtained under the flat bed planting. A B: C ratio of 3.43 was achieved under the raised bed planting against 2.83 under the flat bed planting (Table 1).

Table.1 Comparative study of flat bed planting and raised bed planting methods of chick pea sowing in central India

\begin{tabular}{|l|c|c|c|c|c|c|c|c|c|c|}
\hline Year & \multicolumn{2}{|c|}{$\begin{array}{c}\text { Yield } \\
\text { Q/ha }\end{array}$} & $\begin{array}{c}\text { Average Cost } \\
\text { of cultivation } \\
\text { (Rs/ha) }\end{array}$ & $\begin{array}{c}\text { Average Gross } \\
\text { return } \\
\text { (Rs/ha) }\end{array}$ & $\begin{array}{c}\text { Average Net } \\
\text { Return } \\
\text { (Rs/ha) }\end{array}$ & $\begin{array}{c}\text { Benefit Cost ratio } \\
\text { (Average gross } \\
\text { return / Average } \\
\text { gross cost) }\end{array}$ \\
\hline & FBS & RBS & FBS & RBS & FBS & RBS & FBS & RBS & FBS & RBS \\
\hline $\mathbf{2 0 1 4 - 1 5}$ & 10.3 & 12.8 & 23950 & 24700 & 37970 & 47195 & 14020 & 22495 & 1.58 & 1.91 \\
\hline $\mathbf{2 0 1 5 - 1 6}$ & 13.6 & 17.5 & 24000 & 25500 & 68000 & 87500 & 44000 & 62000 & 2.83 & 3.43 \\
\hline $\begin{array}{l}\text { A verage of three years } \\
(\mathbf{2 0 1 4} \text { to 2016) }\end{array}$ & 11.95 & 15.15 & 23975 & 25100 & 52985 & 67347.5 & 29010 & 42248 & 2.205 & 2.67 \\
\hline
\end{tabular}

FBS - Flat bed sowing; RBS - Raised bed sowing 
Averaging of the two years data was done. The results so obtained are as follows. Crop yield under the flat bed planting was computed to be $11.95 \mathrm{q} / \mathrm{ha}$ whereas the same under the raised bed planting was $15.15 \mathrm{q} / \mathrm{ha}$. Thus an increase of nearly 28 percent was obtained in crop yield when planted on raised beds.

The net return in the case of raised bed planting was Rs. 29010/- per ha whereas that under raised bed planting was observed to be Rs. 42248/- per ha. Thus an increase of Rs. 13238/per ha was observed under the raised bed planting. With regard to $\mathrm{B}$ : $\mathrm{C}$ ratio the one under raised bed planting (2.67) was found to be higher than that under the flat bed planting (2.205). Overall the raised bed planting performed better than the flat bed planting.

The raised bed planting of chickpea provided an environment much suitable for the crop growth. Eventually the crop yield under the raised bed planting was higher than that under the flat bed planting. This is well evident from the results of the two years study. Moreover lesser amount of seed was required under the raised bed planting.

Thus it can be concluded that the raised bed planting is a good option for increasing crop growth in the vertisol regions of central India. Pramanik et al., (2009) in their study of raised bed planting with chickpea have also reported that raised bed planting gave higher grain yield than the flat bed planting.

Khambalkar et al., (2014) in their study on the performance of bed-furrow planter in winter season of dryland crops have reported that there was an increase in yield of chickpea by 12.5 percent using broad bed and furrof system of planting as compared to the traditional flatbed method of sowing. Joshi and Shrivastava (2017) in their study on modification and performance evaluation of tractor drawn raised bed seed drill under vertisol have reported that the average yield of chickpea by raised bed sowing was $1211.3 \mathrm{~kg} / \mathrm{ha}$ as compared to that viz. 1127.83 $\mathrm{kg} / \mathrm{ha}$ under conventional practice.

Thus here also the raised bed sowing outperformed the conventional of sowing of chickpea in vertisols. Hence it can be concluded that the raised bed method of planting is a more suitable option for cultivation of chickpea in vertisols.

\section{References}

Jitendra Joshi \& Atul Kumar Shrivastava (2017): Modification and performance evaluation of tractor drawn raised bed seed drill under vertisol. International Journal of Agricultural Science and Research; Volume 7, Issue 3, June 2017, pp: 385-394.

Khambalkar, V.P., N.N. Waghmare, A.V. Gajakos, D.S. Karale, U.S. Kankal (2014): Performance of broad bed planter in winter season of dryland crops. International Agricultural Engineering Journal, 23(01): 14-22, June 2014.

MOA 2013. Agriculture statistics at a glance 2013: Directorate of Economics and Statistics, Ministry of agriculture, Govt. of India.

Pramanik S.C, Singh N.B., Singh K.K. (2009): Yield, economics and water use efficiency of chickpea (Cicer arietenum) under various irrigation regimes on raised bed planting system. Indian Journal of Agronomy, Year 2009, Volume -54, Issue -3, pp: 315-318.

\section{How to cite this article:}

Prashant Shrivastava, Yati Raj Khare and Pahalwan, D.K. 2018. Performance of Chickpea under Raised Bed Planting in Vertisols in Central India. Int.J.Curr.Microbiol.App.Sci. 7(03): 810-812. doi: https://doi.org/10.20546/ijcmas.2018.703.094 